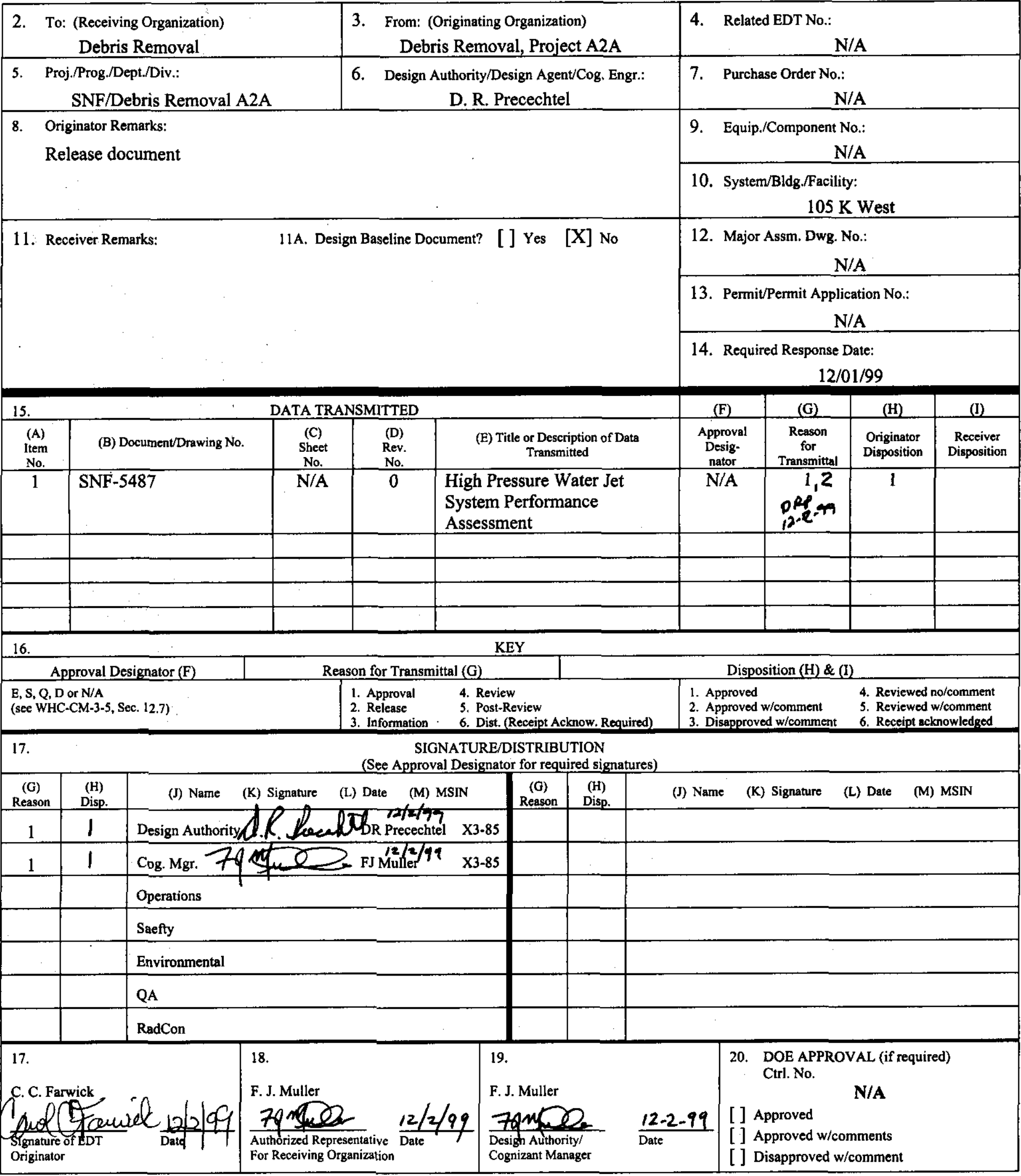




\section{DISTRIBUTION SHEET}

\begin{tabular}{|c|c|c|c|c|c|}
\hline \multirow{2}{*}{$\begin{array}{l}\text { To: } \\
\text { Distribution } \\
\end{array}$} & \multirow[t]{2}{*}{ From: } & \multirow{2}{*}{\multicolumn{2}{|c|}{ C. C. Farwick }} & \multirow{2}{*}{\multicolumn{2}{|c|}{\begin{tabular}{|l|} 
Page 1 of 1 \\
Date: December 1,1999 \\
\end{tabular}}} \\
\hline & & & & & \\
\hline \multirow{2}{*}{\multicolumn{4}{|c|}{$\begin{array}{l}\text { Project Title/Work Order } \\
\text { High Pressure Water Jet System Performance Assessment, Project A2A - } \\
\text { SNF-5487, Rev. } 0\end{array}$}} & \multirow{2}{*}{\multicolumn{2}{|c|}{$\begin{array}{ll}\text { EDT No. } & 627339 \\
\text { ECN No. } & \\
& \text { N/A } \\
\end{array}$}} \\
\hline & & & & & \\
\hline Name & MSIN & $\begin{array}{l}\text { Text } \\
\text { With All } \\
\text { Attach. }\end{array}$ & $\begin{array}{l}\text { Text } \\
\text { Only }\end{array}$ & $\begin{array}{c}\text { Attach./ } \\
\text { Appendix } \\
\text { Only }\end{array}$ & $\begin{array}{c}\text { EDT/ECN } \\
\text { Only }\end{array}$ \\
\hline C. A. Bullock & $\mathrm{X3}-68$ & $\mathrm{X}$ & & & \\
\hline D. E. Bullock & R3-86 & $\mathrm{X}$ & & & \\
\hline C. C. Farwick & $X 3-85$ & $\mathrm{X}$ & & & \\
\hline J. D. Mathews & X3-65 & $\mathrm{X}$ & & & \\
\hline \multirow{2}{*}{$\begin{array}{l}\text { F. J. Muller } \\
\text { D. R. Precechtel }\end{array}$} & $\mathrm{X} 3-85$ & $\mathrm{X}$ & & & \\
\hline & $\mathrm{X} 3-85$ & $\mathrm{x}$ & & & \\
\hline \multirow[t]{2}{*}{ K Basin Project Files A.13 } & X3-85 & $\mathrm{X}$ & & & \\
\hline & & & & & \\
\hline
\end{tabular}




\title{
High Pressure Water Jet System Performance Assessment - Project A2A
}

\author{
C. C. Farwick for \\ Fluor Daniel Hanford \\ Richland, WA 99352 \\ U.S. Department of Energy Contract DE-AC06-96RL13200 \\ EDT/ECN: $627339 \quad$ UC: 2000 \\ Org Code: $2 \mathrm{G} 400$ Charge Code: 105612 \\ B\&R Code: EW7040000 Total Pages: 2315.15 .49$.
}

Key Words: Performance Assessment, Lessons Learned, HPWJS, K East (KE).

Abstract: Performance assessment for canister cleaning system in the KE Basin. Information obtained from this assessment will be used to design any additional equipment used to clean canisters.

TRADEMARK DISCLAIMER. Reference herein to any specific commercial product, process, or service by trade name, trademark, manufacturer, or otherwise, does not necessarily constitute or imply its endorsement, recommendation, or favoring by the United States Government or any agency thereof or its contractors or subcontractors.

Printed in the United States of America. To obtain copies of this document, contact: Document Control Services, P.O. Box 950, Mailstop H6-08, Richland WA 99352, Phone (509) 372-2420; Fax (509) 376-4989.
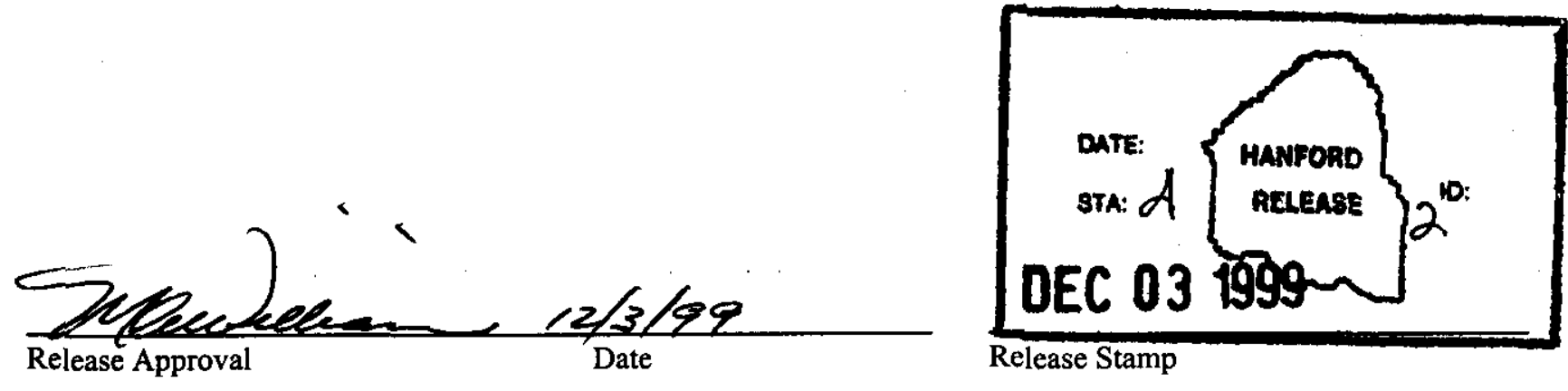

\section{Approved for Public Release}


SNF-5487, Rev. 0

Project A.2.A

\section{TABLE OF CONTENTS}

1.0 SUMMARY OF FINDINGS AND RECOMMENDATIONS....................................1

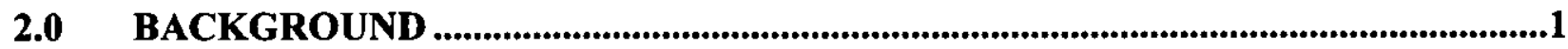

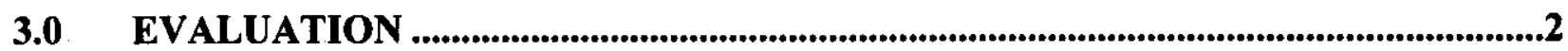

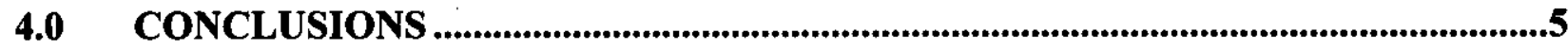

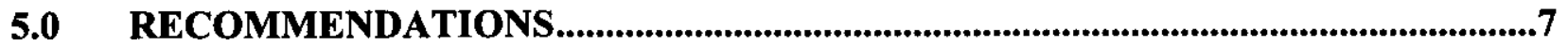

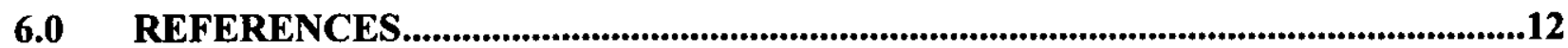




\subsection{SUMMARY OF FINDINGS AND RECOMMENDATIONS}

After thorough review of the design, maintenance history and operational characteristics of the $105 \mathrm{~K}$ East (KE) canister cleaning system, Bartlett recommends that the high pressure water jet system (HPWJS) be modified as outlined in section 5.0, and retained for future use. Further, it is recommended that Spent Nuclear Fuel (SNF) Project consider use of a graded approach for canister cleaning, based on individual canister type and characteristics. This approach would allow a simple method to be used on canisters not needing the more rigorous, high-pressure method. Justification is provided in section 5.0. Although Bartlett has provided some preliminary cost estimates, it is recommended that SNF Project perform a detailed cost-benefit analysis to weigh the alternatives presented.

\subsection{BACKGROUND}

\section{Equipment Description}

The KE Canister Cleaning Equipment includes:

- An above water, Butterworth $®$ Jetting Systems, Model 615 ES, high pressure water jet skid assembly

- A below water canister cleaning fixture

- A primary operator control station with three (3) foot activated control valves,

- A greenhouse and bagging station.

Accessories include an overhead 300-pound hoist, telescoping stiff back assembly, 150-foot highpressure hose, connecting the skid to the operator station, and various fuel-handling tools. The system is designed to operate at 15,000 pounds per square inch (psi), at a flow rate of 15 gallons per minute (gpm). The high-pressure water pump skid is located west of the south loadout pit in the $105 \mathrm{KE}$ transfer bay area. All other equipment is located in the center basin where an 8' X 14' cutout in the basin grating provides access. All equipment is non-safety class.

\section{Equipment Manufacturer}

Equipment for the canister cleaning system was supplied under P.O. contract \# MDK-SIV-405122 by O'Connell Jetting Systems, Benicia, California. Scientific Ecology Group (SEG), Richland, Washington, provided engineering services. The equipment is no longer covered under warranty. 


\section{$\underline{\text { SNF Debris Removal Project }}$}

The canister cleaning system was installed in 1996 as part of the SNF Debris Removal Project. The project mission was to remove empty fuel canisters, poles, and other debris which had accumulated in the basin. Debris removal was necessary to support fuel movement and sludge removal from the $\mathrm{KE}$ and $\mathrm{K}$ West $(\mathrm{KW})$ Basins.

During the canister cleaning campaign over 1400 canisters were cleaned and disposed of as low-level waste. However, the equipment experienced many breakdowns, which either halted production or reduced equipment effectiveness due to inoperable components. It should be noted that although the equipment experienced significant downtime, the overall mission was successfully completed on schedule.

A work package, 1K-99-00152/M, has been prepared to isolate, drain and electrically disconnect the HPWJS. The work package is scheduled for completion in August 1999. The equipment currently remains in wet lay up at $105 \mathrm{KE}$.

\subsection{EVALUATION}

A review of the design, maintenance history and operational characteristics of the HPWJS was completed in accordance with contract \# 2990. This review consisted of interviews with SNF personnel, discussions with the manufacturer, and a thorough review of operating and maintenance procedures, system descriptions, vendor submittals, and engineering drawings. Additionally, a system walk-down was performed.

\section{HPWJS Assessment}

In 1997, a team made up of subject matter experts from K Basin Project Engineering, Radiation Control, Maintenance and Operations performed an assessment of the HPWJS. Their mission was to document for management the cost of increasing the availability of the HPWJS to $75 \%$ or greater or provide other options for canister cleaning and their associated costs. From this assessment a list of recommendations was created. These recommendations form the baseline from which all recommendations may be compared against. Appendix A contains the current status of the 1997 recommendations.

\section{$\underline{\text { Interviews }}$}

Interviews were conducted from June 1 to June 24, 1999, with SNF personnel from K Basin Operations, Radiation Control, Project Engineering, Maintenance \& Work Control, and Operations Analysis \& Waste Handling (OA\&WH). Personnel interviewed and the results of those interviews are summarized in the paragraphs below. 
K Basin Operations

Radiation Control/ALARA

Project Engineering

Maintenance \& Work Control

Operations Analysis and

Waste Handling (OA\&WH)
Dan Funk - Facility Operator

Mike Precechtel - Facility Operator

Terry Houston - Facility Operator

Chevo Campos - Facility Operator

Tom Ruane - Operations Manager

Jeff Bailey - Former N-Reactor Operator

Shirley Ostboe - Operations Training

Al Pitner - Fuel Accountability

Todd Southerland - HP Manager

Don Precechtel - Project Engineer

Frank Muller - Project Manager

Mike Langevin - Cognizant Engineer

R.R. (Dick) Anderson - Discipline Engineer

Alvin Keck - Spare Parts and Inventory Control

Fred Catlin - Millwright

Greg Herrin - Work Planner

Kenny Shollenberger - Person-in-Charge, PIC

Robert (Bob) Barnett - Millwright

Rod Jochen - OA\&WH Engineer

\section{General Comments - Equipment Related}

Numerous equipment failures slowed down production. These failures included:

- nozzle erosion

- fretting of the high pressure hose

- fitting leaks

- electrical switch and relay failures

- hoist failures

- glovebox tears in elephant trunk

These failures appear to be related to system pulsation and vibration. They increased worker radiological exposure due to increased inspections and maintenance. 
1. Nozzle replacements required the cleaning equipment to be removed from the pool. Movement of equipment in and out of the pool is considered a critical lift evolution. The critical lift evolutions required extensive paperwork and coordination, requiring up to 8 hours of setup time to perform a 15-minute nozzle replacement. Nozzle replacements also required extensive radiological controls and radiological paperwork. However, the radiological protection staff worked closely with the project personnel to streamline the paper requirements. Nozzle replacement required donning full-face respirators, slowing communications and increasing the work evolution.

2. Operation and maintenance of the equipment was tedious and it took excessive time because of the general arrangement of equipment in the basin. For Operations personnel, there was too little space due to the monorail and hoist, which made it difficult to maneuver the cleaning fixture and the telescoping stiff back.

3. The original greenhouse was not durable enough to hold up to production cleaning and had to be re-fabricated. The bag station glove box was changed out to plexi-glass. Additionally, the glove ports in the elephant truck failed due to lack of flexibility between the elephant truck and its support frame (the attachment was not forgiving of any stress or strain).

4. Excess noise level from the pump skid interfered with communication. When the system was operating, the noise level was approximately 90 decibels $(\mathrm{db})$. Earplugs were required and communication was difficult. Radios and other devices were used between the Pump Operator (located at the pump skid) and the Primary Operator (located at the cleaning station) with little success.

5. The life span of high-pressure water jet nozzles was very short. The nozzles eroded prematurely causing the spin jets to fail to spin. When the spin jets began to fail, their cleaning efficiency was significantly reduced. Replacing nozzles was time consuming.

It was generally noted that when the system was running properly, the canisters were cleaned efficiently and within the established radiological criteria.

\section{General Comments - Programmatic}

- Different Operating Shifts (Shift Supervisors and Operators) had different levels of training and experience using the equipment causing large variations in both production and breakdowns. A typical operating crew consisted of five (5) people: four (4) Operators and one (1) Radiation Control Technician (RCT).

- There was minimal training provided to operations personnel and no training provided to maintenance personnel on the equipment even though the equipment was new and had unique maintenance problems due to very high pressure $(15,000 \mathrm{psi})$ during operation.

- The continued lack of equipment reliability added to the level of frustration for operating crews. 


\section{Specific Comments}

Project Engineering - The amplitude of vibration on the pump skid was so high that it would shake electrical relays out of their mounting sockets. This vibration was the cause of most skid related equipment failures. The electrical panels were eventually moved off the skid. Failures appeared random in nature and were so frequent that reliability studies of equipment performance was impractical. Nozzle life was considerably less than expected. The vendor had indicated nozzle life to be approximately fifty (50) hours. Actual nozzle life was as low as five (5) hours.

\subsection{CONCLUSIONS}

The $105 \mathrm{KE}$ canister cleaning campaign was successfully completed in September 1997. Approximately 1400 canisters were cleaned and disposed of as low-level waste. When the HPWJS was working properly, it performed well. At optimum performance, cleaning efficiency was very good. However, the equipment experienced many failures. Repeated breakdowns created a demoralizing affect on operations, maintenance and engineering personnel.

Additionally, many more basin entries were necessary to evaluate, repair and/or replace failed components. Had the equipment been more reliable, total personnel exposure for canister cleaning would have been significantly reduced.

Bartlett concludes that inadequacies in the original system design are the primary cause of the excessive number of equipment failures and overall discontent with the system. Additionally, there were other programmatic issues dealing with lack of training, experience and supervision which contributed to the high failure rate. These factors are described in more detail in the following paragraphs

\section{Ergonomic Factors}

The lack of attention to human factors and ergonomics was evident when looking at the general arrangement of equipment, particularly at the operator cleaning station. Many interference problems existed. The operator handle for rotational movement of the outer nozzles was positioned much too high to be repeatedly used effectively. Additionally, if not closely monitored, the handle would bind on the top of the air motor at the bottom end of its travel.

Location of the handrails, on the West Side of the grating opening, made it difficult during loading to hook and place the canister on the cleaning table. The operator had to strain to reach across the handrail. This was especially difficult when loading the heavier stainless steel canisters. It is also speculated that congestion at the operator station caused several incidents of mis-positioning of the 300-pound hoist. On at least one occasion, the cleaning table was hooked and pulled up and out of position as a result. Lack of operator knowledge on hoist operation may have also contributed to some of the hoist failures.

\section{$\underline{\text { Nozzles }}$}

Based on the operating history and discussion with key personnel, the nozzles are considered to be the weak link in the effective operation and availability of the equipment. This can also be attributed to inadequacies in the original design. 
The equipment was designed for commercial operation with the skid mounted on a truck. The truck tires, springs and shock absorbers would act to dampen the vibration. Also, in the industrial environment (air), nozzle replacement would be quick and simple thus minimizing down time and maximizing system performance. This was not the case in the basin. The skid was temporarily set in a drip pan in the transfer bay area with minimal damping. Many components were mounted on stands, which accentuated the amplitude of vibration during operation. The nozzles were mounted at the bottom of the cleaning fixture assembly 16 feet below the surface of radioactively contaminated water.

Experience indicated that the nozzle life expectancy was much less than originally expected. Once the nozzles degraded, system performance suffered due to large pressure drops in the system. One $\mathrm{K}$ Basin pipefitter witnessed a drop in gauge pressure at the high-pressure manifold from 15,000 psig to 2,000 psig. Because the effect of nozzle erosion was not thoroughly understood until the later portion of the project and because nozzle change out was time intensive, the nozzles were not changed out as frequently as required for optimum cleaning efficiency and equipment reliability. Different nozzles were considered but never tried due to problems with the vendor, low spare part inventories, and the added expense of procuring higher quality nozzles.

\section{Programmatic Issues}

The following are programmatic issues, which contributed to poor system performance.

- Differences in operating crews (shifts) with varying degrees of training and experience. Interviews conducted with operations personnel indicated that there was a wide variation in acceptance of the cleaning system. Some crews were supervised on shift, while others were not. The inconsistencies in composition of the crews, the level of training and the effectiveness of supervision caused large variations in equipment failures and production goals.

- Lack of pre-approved work packages for performance of preventive and corrective maintenance. During interviews, one engineer stated that a significant amount of time was spent preparing work packages when inspection and/or maintenance on the equipment was required. He further suggested that pre-approved work packages might have cut this time considerably thus improving equipment availability. A review of existing, pre-approved maintenance procedures indicated that procedures did exist for most types of maintenance. However, based on the number and type of failures experienced over the fifteen months of operation, many more pre-approved procedures could be written to expedite inspection, troubleshooting and repair.

- Lack of sufficient spare part inventory to support required maintenance. No spare parts were ordered or supplied with the original equipment. The lack of spare parts, particularly consumable parts, and long lead-time made it difficult to perform preventive maintenance at regular intervals. This "run to failure" philosophy added unnecessary delays which could have been eliminated had sufficient stock of parts been available. Additionally, there was some confusion with the vendor over part numbers. On at least one occasion, the vendor supplied the wrong parts. The Inventory Tracking and Control System was also out of date and has not been upgraded yet due to lack of funds. 


\subsection{RECOMMENDATIONS}

Bartlett recommendations for disposition of the High Pressure Water Jet System are summarized below. A detailed cost-benefit analysis of the recommendations provided should be performed. Final recommendations include:

- Complete Remaining 1997 Baseline Modifications (Refer to Appendix A)

- Modify HPWJS to Lower Operating Pressure to 8500 psi

- Provide a Manual Cleaning Station at Predetermined Location in Basin

All three recommendations contain important elements necessary for optimum system reliability, availability and cleaning efficiency. An itemized accounting, in matrix form, for individual elements of all recommendations is provided in Appendix C. The matrix allows SNF Project to review, evaluate and prioritize individual elements of each recommendation to determine which modifications are acceptable to SNF Project for implementation based on current and projected project funding and schedule. A detailed description, including justification, of each recommendation is provided under the applicable subheading below. Table 1 shows the individual breakdown of modifications and program improvements required to implement each recommendation along with its associated cost.

\section{Complete Remaining 1997 HPWJS Baseline Modifications}

\section{Justification:}

- The original capital expenditure would not be lost and the system would be retained for use in some capacity.

- When the HPWJS is running properly it has high cleaning efficiency.

- Cleaned canisters meet low level waste criteria for disposal.

- Performing the recommended modifications should increase equipment reliability and availability to acceptable levels.

- Because there would be minimal design changes to the HPWJS, the existing stock of spare parts could be used up.

Bartlett recommends that those cost effective baseline improvements presented in the original 1997 HPWJS Performance Assessment be completed as outlined in Appendix A. These recommendations relate to equipment modifications, program improvements and the required update of current design information. Some of the required modifications were completed prior to the system being placed in wet lay-up at $105 \mathrm{KE}$. Table 1 below summarizes all the remaining modifications and their associated costs for completion. For comparison purposes, total costs associated with this recommendation are provided in matrix format. (Refer to Appendix C.) All cost estimates were taken from the 1997 assessment report, except where noted. Material costs, where possible, were obtained from the original equipment distributor. Labor costs were calculated based on time and hourly rates furnished by the Project Manager. All assumptions used have been noted. 
It should be noted that completion of the baseline improvements would not alter the original operating pressure of $15,000 \mathrm{psi}$ at $15 \mathrm{gpm}$, but would significantly improve system availability/reliability and cleaning efficiency.

\section{Lower HPWJS Operating Pressure to 8,500 psi}

\section{Justification:}

Lowering operating pressure should:

- significantly reduce failures associated with high amplitude of vibration;

- extend nozzle life; and

- minimizes safety concerns associated with operating at ultra-high pressure.

In addition to implementation of the baseline modifications previously discussed, Bartlett recommends that the operating pressure of the HPWJ system be lowered to 8,500 psi. Additional program enhancements are also recommended. These additional modifications and their associated costs are itemized in Table 1. Total cost associated with this recommendation is included in Appendix C.

Note that no further modification of the operator cleaning station would be required to implement this recommendation and it is probable that this modification would further improve system availability/reliability by as much as $10 \%$ without a significant change in cleaning efficiency.

Provide a Manual Cleaning Station at a Predetermined Location in the Basin

\section{Justification:}

- A manual cleaning station would simplify the process without the safety concerns and maintenance aspects of high-pressure cleaning. It would also provide a backup if equipment failure rendered one method inoperable for extended periods of time.

- Simplified manual cleaning method would require little, if any, operator training

- Nozzle replacement on the portable unit would be relatively simple.

$\mathrm{KE}$ and $\mathrm{KW}$ basins contain a mixture of MK-0, MK-I, and MK-II fuel canisters. Canister count based on canister type for each basin is provided in Appendix B. Canister type is easily distinguishable in the basin. The older canisters are fabricated from aluminum. Newer versions are fabricated from stainless steel. Past experience has shown that the old aluminum canisters have degraded due to corrosion and exhibit a higher degree of surface deposits. Consequently, the aluminum canisters have been harder to clean to the acceptable radiological release limit of $100 \mathrm{mR}$ (at $30 \mathrm{~cm}$ ). 
A manual cleaning station would allow a simple brush and rinse method to be used on stainless steel canisters and possibly some aluminum canisters not requiring the more rigorous high pressure cleaning. Some pre-planning during the fuel retrieval process would be required for optimum results. Ideally, an Operator would perform an initial screening during the fuel retrieval process. This screening would evaluate the canister based on canister type, material and surface condition. The newer stainless steel canisters and those aluminum canisters in good condition would be segregated and stored for cleaning at the manual cleaning station. Older canisters, exhibiting a high degree of surface deposits and those canisters which could not be acceptably cleaned by the brush and rinse method, would be set aside for high pressure cleaning using the modified HPWJS. The required system and program changes for this recommendation are described Table 1 . Total costs for this recommendation are included in Appendix C.

\section{Other Alternatives for Consideration}

In addition to the detailed recommendations presented in this report, Bartlett further recommends that SNF Project explore other promising design alternatives. For example, one option would be to modify the current canister cleaning fixture such that the canister would move up and down past a set of fixed nozzles. This change would provide for easier nozzle change out during maintenance thus increasing system availability while, at the same time, minimize interference problems, which currently exist at the operator cleaning station as originally designed. 
Table 1 - Summary of Recommendations

\begin{tabular}{|c|c|c|c|c|}
\hline \multirow{2}{*}{\multicolumn{2}{|c|}{ 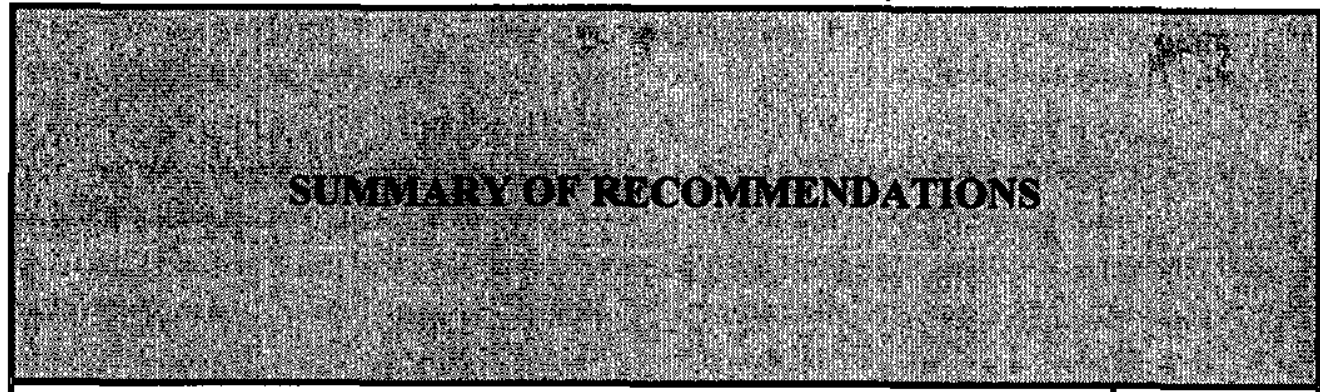 }} & \multicolumn{3}{|c|}{ Recommendations } \\
\hline & & \multirow[t]{2}{*}{ 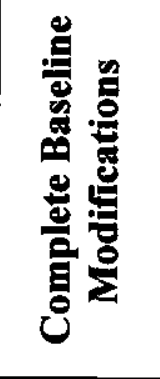 } & \multirow[t]{2}{*}{ 里 } & \multirow[t]{2}{*}{ 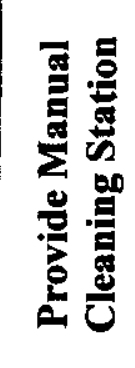 } \\
\hline Item Description & Cost & & & \\
\hline $\begin{array}{l}\text { 1) Skid Modifications } \\
\text { - relocate HPWJ manifold, regulator valve and HP hose } \\
\text { - } \text { install sheath protection for HP hose } \\
\text { - replace } 10 \text { micron filter with } 5 \text { micron filter } \\
\text { - procure tube wrenches for hose replacement } \\
\text { - re-build equipment (hot shop) } \\
\text { - modify HPWJS installation (drip pan) } \\
\text { - procure and install new fluid end for } 8500 \text { psi @ } 27 \mathrm{gpm} \\
\text { - operation } \\
\text { - } \text { procure and install high-pressure hoses } \\
\text { - remove pressure surge tank } \\
\text { 2) Canister Cleaning Station Modifications } \\
\text { - fabricate and install new elephant trunk } \\
\text { - replace Teflon bushings with brass where necessary } \\
\text { - } \text { stabilize t-support bracket } \\
\text { - replace spin jets with stationary nozzles } \\
\text { - shorten poles \& other misc. items } \\
\text { - re-design swing arm } \\
\end{array}$ & $\begin{array}{r}\$ 6,500 \\
\$ 500 \\
\$ 500 \\
\$ 200 \\
\$ 15,000 \\
\$ 5,000 \\
\end{array}$ & $\begin{array}{l}\checkmark \\
\checkmark \\
\checkmark \\
\checkmark\end{array}$ & $\begin{array}{l}\boldsymbol{V} \\
\boldsymbol{\gamma}\end{array}$ & $\checkmark$ \\
\hline $\begin{array}{l}\text { Equipment Modification Subtotal (\$) } \\
\end{array}$ & 7. & 107,200 & 110,412 & 11,600 \\
\hline $\begin{array}{l}\text { 3) New Equipment } \\
\text { Procure portable power washer capable of } 2500-3500 \text { psi } \\
\text { for cleaning } \\
\text { - Procure Chimney brushes and drill motors used for cleaning } \\
\text { - Fabricate \& install manual cleaning station in basin } \\
\text { - Procure \& install HP hose rated @ } 8500 \text { psi } \\
\text { - Procure required pressure fittings }\end{array}$ & $\begin{array}{r}\$ 11,600 \\
\$ 3,500 \\
\$ 1,200 \\
\end{array}$ & $\sqrt{ }$ & $\sqrt{ }$ & $\begin{array}{l}\checkmark \\
\checkmark\end{array}$ \\
\hline New Equipment Subtotal (\$) & & 0 & 3,825 & 26,700 \\
\hline
\end{tabular}




\begin{tabular}{|c|c|c|c|c|}
\hline \multirow{2}{*}{\multicolumn{2}{|c|}{ W }} & \multicolumn{3}{|c|}{ Recommendations } \\
\hline & & \multirow[t]{2}{*}{ 量递 } & \multirow[t]{2}{*}{ 电是 } & \multirow[t]{2}{*}{ 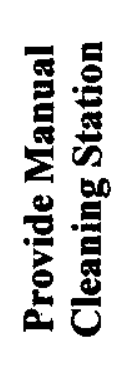 } \\
\hline Item Description & Cost & & & \\
\hline Program Improvements & Costs & & & \\
\hline $\begin{array}{l}\text { 1) Maintenance and Work Control } \\
\text { - Develop additional maintenance procedures and streamline } \\
\text { work planning process } \\
\text { - Upgrade Inventory Tracking \& Control System } \\
\text { - Maintain sufficient stock of spare parts } \\
\text { 2) Training Programs } \\
\text { - Develop on-the-job training (OJT) checklist } \\
\text { - Develop Operator Training Qualification Program } \\
\text { 3) Technical Services } \\
\text { - Revise current operating procedures } \\
\text { - Develop new/revise current operating procedures as } \\
\text { 4) Engineering Changes } \\
\text { - Perform evaluations, write PMs, design changes, } \\
\text { - track/record availability } \\
\text { - Uevise design requirements and drawings } \\
\text { - Design manual cleaning station in basin }\end{array}$ & $\begin{array}{l}\$ 13,500 \\
\$ 22,600 \\
\text { TBD } \\
\$ 1,780 \\
\$ 14,000\end{array}$ & $\begin{array}{l}\checkmark \\
\checkmark\end{array}$ & $\checkmark$ & $\checkmark$ \\
\hline Program Improvement Subtotals (\$) & 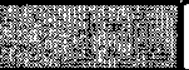 & 113,750 & 115,650 & 43,530 \\
\hline Totals (\$) & & 205,950 & 229,887 & 81,830 \\
\hline $\begin{array}{l}\text { Notes: } \\
\text { 1) All cost estimates taken from "1997 HPWJS Assessment Rep } \\
\text { where noted (shaded). } \\
\text { 2) Shaded costs denote calculated costs using time and hourly ra } \\
-\quad \$ 50 / \mathrm{hr} \text { for craft personnel } \\
\text { - } \$ 75 / \mathrm{hr} \text { for Engineering personnel } \\
\text { 3) Unable to estimate spare parts cost since amount dependent }\end{array}$ & s provided & & ents. & \\
\hline
\end{tabular}




\subsection{REFERENCES}

\section{$\underline{\text { Source Documents }}$}

1. HNF-SD-SNF-SDD-014, Rev 0, "System Design Description for the K Basins Fuel Handling System".

2. WHC-SD-SNF-FRD-018, Rev. 0, "Functions and Requirements for Debris Removal from 105KE Basin South Loadout Pit".

3. Manufacturer Operation and Maintenance Manual, CVI \# 18540

Technical Procedures

1. Operations Procedure, OP-07-101, Rev. 1/L, "Operate High Pressure Water Jet System".

2. Maintenance Procedure, MP-07-001, Rev. 0/A, "High Pressure Water Jet System Maintenance".

3. Maintenance Procedure, MP-07-002, Rev. 0/A, "Canister Cleaning Fixture Nozzle Replacement".

\section{Drawings}

1. H-1-81462, Rev. 0, "Canister Cleaning High Pressure Washer-P \& ID”. (Essential Drawing)

2. H-1-82086, Rev. 0, "Canister Cleaning Wand Assembly".

3. H-1-82088, Rev. 0, "Telescoping Stiffback Assembly".

\section{Work Packages}

1. 1K-97-00164M, Status- Cancelled 2/26/98, "Modify High Pressure Water Jet System Pump Skid and High Pressure Manifold".

2. 1K-97-00166M, Status- Cancelled 2/23/98, "Add Bracing for Canister Cleaning Heads-KE”.

3. $1 \mathrm{~K}-99-00152 / \mathrm{M}$, "Isolate and Drain HPWJS", Status- Work package is scheduled for work in August 1999 


\section{Correspondence}

1. Don't Say it Write it (DSI), Dated 10/31/96, From Kurt Lenkendorfer, To Alvin Keck, "Spare Parts List for High Pressure Water Jet Cleaning System".

2. Master Lee Hanford Corporation Letter, Dated 3/10/97, From Don Kooser, To Frank Moore, "HPWJS Tiger Team

3. Document \# 9603136, Dated 12/12/96, From Elizabeth D. Sellers, Director-DOE, To H.J. Hatch, President-Flour Daniel Hanford, "K Basin Debris Removal Project"

4. Document \# 2A200-97RJL-002, Dated 02/1 1/97, From, Richard J. Lodwick, Director-SNF Facility Project, To, D. W. Siddoway, "Canister Cleaning Engineering Team"

\section{Other References}

1. 1997 HPWJS Performance Assessment (tiger team report)

- Performance evaluation

- Root cause analysis worksheets

- Meeting minutes

- Cost estimates 